
університету. - Серія "Регіональна економіка". - Випуск 15 (59). - Редкол.: відп. ред. д.е.н., професор Л.Л. Ковальська. - Луцьк: ІВВ Луцького НТУ, 2018. - 292 с.

УДК $331.5(477)$

Шубала I.В., к.е.н., доцент

Луцький національний технічний університет

\title{
ТЕНДЕНЦІЇ ТА ЗАКОНОМІРНОСТІ ВИКОРИСТАННЯ РОБОЧОГО ЧАСУ В РЕГІОНІ
}

У статті вивчено тенденції та закономірності використання робочого часу на прикладі Волинської області.

Ключові слова: робочий час, відпрацьований час, втрати робочого часу, працівники, регіон.

\section{Shubala I.}

\section{TRENDS AND REGULARITIES OF USING WORKING TIME IN THE REGION}

In conditions of reforming labor legislation, the study of regulation of working time, in particular its theoretical and applied aspects, becomes of particular relevance. The rationality and completeness of the use of working time depends to a large extent on wages and the level of additional social guarantees for employees at different levels of government. An indication of the inappropriateness of using working time is its loss. Study of the losses of working time should be carried out continuously by analyzing the structure of working time, identifying the causes of non-compliance norms, irrational costs of working time, as the time spent by workers is the main measure of labor.

The purpose of the study is to study the trends and patterns of the use of working time workers in the Volyn region.

Describing the tendencies of changing the time worked per employee in the Volyn region, one can conclude that the lowest level is mainly provided by the branches of the non-productive sphere, which belong to the budget sphere, where social guarantees for workers who are in temporary disability or on leave, while in the branches of the manufacturing sector, this indicator is usually higher, because employers encourage employees to use work time rationally, because the level depends on this wages and the amount of employer's expenses for staff retention.

In general, it can be concluded that in the area of working time in the region there are mainly positive changes. After all, the growth of the time worked per worker per annum is ensured, and the non-working out of the reasons for the leave without saving salary or transfer to part-time (week). Accordingly, there is a steady trend towards a decrease in the number of employees on leave without salary waivers (for the period of termination of work), as well as for part-time workers transferred for economic reasons. This generally suggests that more full use of 
Економічні науки: збірник наукових прачь Луиького національного технічного університету. - Серія “Регіональна економіка". - Випуск 15 (59). - Редкол.: відп. ред. д.е.н., професор Л.Л. Ковальська. - Луцьк: ІВВ Луиького НТУ, 2018. - 292 с.

working time in the region. Over the majority of economic activities, the region's time use of working time in 2017 increased compared to 2015, although in the area of providing other services, it dropped from $87.6 \%$ in 2015 to $82.8 \%$ in 2017 , indicating deterioration use of working time in this area. The results of the forecast suggest that the trend towards the increase of the working time in $\%$ to the working time table in the Volyn region will continue and by 2019 this figure may reach $86 \%$. That is, there are mainly positive changes to the increase in the use of working time in the region.

Keywords: working time, time worked, lost time, workers, region.

\section{Шубала И.В.}

\section{ТЕНДЕНЦИИ И ЗАКОНОМЕРНОСТИ ИСПОЛЬЗОВАНИЯ РАБОЧЕГО ВРЕМЕНИ В РЕГИОНЕ}

В статье изучены тенденции и закономерности использования рабочего времени на примере Волынской области.

Ключевые слова: рабочее время, отработанное время, потери рабочего времени, работники, регион.

Постановка проблеми у загальному вигляді і її зв'язок 3 важливими науковими та практичними завданнями. Від раціональності та повноти використання робочого часу значною мірою залежить заробітна плата та рівень додаткових соціальних гарантій працівникам на різних рівнях управління. Ознакою нераціональності використання робочого часу є його втрати. Вивчення втрат робочого часу повинно проводитись постійно шляхом аналізу структури робочого часу, виявлення причин невиконання норм, нераціональних витрат робочого часу, так як відпрацьований працівниками час $є$ основним вимірником праці. Отже, питання ефективності використання робочого часу завжди буде актуальним на підприємствах, так як саме цей показник впливає на продуктивність праці і кінцеві результати господарської діяльності.

Аналіз останніх досліджень, у яких започатковано вирішення проблеми. Дослідженню питань правового регулювання робочого часу і часу відпочинку присвячені роботи багатьох вчених, таких як: В.С. Венедиктов, В.М. Венідіктова, Л.П. Гаращенко, Л.Я. Глінцбург, М.І. Гордієнко, А.М. Курінний, 
Економічні науки: збірник наукових пращь Луцького національного технічного університету. - Серія “Регіональна економіка". - Випуск 15 (59). - Редкол.: відп. ред. д.е.н., професор Л.Л. Ковальська. - Луиьк: ІВВ Луиького НТУ, 2018. - 292 с.

О.В. Лавриненко, Л.А. Муксінова, Л.Я. Островський, C.M. Прилипко, O.I. Процевський, H.M. Хуторян, О.М. Ярошенко тощо. Проте в умовах реформування трудового законодавства, дослідження регулювання робочого часу, зокрема його теоретичних i прикладних аспектів, набуває особливої актуальності.

Цілі статті. Мета дослідження полягає у вивченні тенденцій i закономірностей використання робочого часу працівників у Волинській області.

Виклад основного матеріалу дослідження 3 повним обгрунтуванням отриманих наукових результатів. На початковому етапі аналізу вивчено динаміку основних показників, що характеризують використання робочого часу у Волинській області за 2010-2017рр. (табл. 1).

Вивчення динаміки показника відпрацьованого робочого часу у розрахунку на одного штатного працівника у Волинській області свідчить про наявність тенденції до його поступового зростання - з 1597 год у 2015 році до 1679 год у 2017 році, або на $5,1 \%$. Хоча у 2017 році відбулося його зменшення до попереднього року на $0,4 \%$, а у 2016 році - зростання на $2,1 \%$.

Разом $з$ тим зміна показників невідпрацювання 3 причин відпустки без збереження заробітної плати (на період припинення виконання робіт) суттєво зменшилася - 313 год у 2010 до 2 год у 2016 році, а у 2017 році втрати робочого часу 3 цих причин бути відсутні взагалі. Щодо аналізу зміни показника невідпрацювання 3 причин переведення 3 економічних причин на неповний робочий день (тиждень), то цей показник також мав тенденцію до зниження - 358 год у 2010 році до 6 год у 2017 році, тобто зменшився майже у 10 разів. Аналізуючи зміну кількості працівників, які знаходились у відпустках без збереження заробітної плати (на період припинення виконання робіт), можна констатувати також зменшення даного показника протягом аналізованого періоду - 3 14,5 тис осіб у 2010 році до 1,4 тис осіб у 2017 році, або також майже у 10 разів, що свідчить про позитивні зміни у роботі підприємств регіону в питанні використання робочого часу. 
Таблиця 1 Динаміка основних показників, що характеризують використання робочого часу у Волинській області за 2010-2017 pp.

\begin{tabular}{|c|c|c|c|c|c|c|c|c|c|c|c|c|}
\hline Показники & \multicolumn{6}{|c|}{ Роки } & \multicolumn{3}{|c|}{ Абсол. відх. } & \multicolumn{3}{|c|}{ Відносн. відх., \% } \\
\hline $\begin{array}{l}\text { У } \quad \text { розрахунку на одного } \\
\text { штатного працівника, год: }\end{array}$ & & & & & & & & & & & & \\
\hline відпрацьовано & 1597 & 1654 & 1641 & 1651 & 1685 & 1679 & 34 & -6 & 82 & 2,1 & $-0,4$ & 5,1 \\
\hline невідпрацьовано за причинами: & & & & & & & & & & & & \\
\hline $\begin{array}{lcc}\text { відпустки } & \text { без } & \text { збереження } \\
\text { заробітної } & \text { плати } & \text { (на період } \\
\text { припинення виконання робіт) }\end{array}$ & 13 & 2 & 2 & 1 & 2 & 0 & 1 & -2 & -13 & 100,0 & $-100,0$ & $-100,0$ \\
\hline $\begin{array}{l}\text { переведення } 3 \text { економічних при- } \\
\text { чин на неповн. роб. день (тижд) }\end{array}$ & 58 & 15 & 17 & 14 & 10 & 6 & -4 & -4 & -52 & $-28,6$ & $-40,0$ & $-89,7$ \\
\hline $\begin{array}{l}\text { Кількість працівників, які } \\
\text { знаходились у відпустках без } \\
\text { збереження зарплати (на період } \\
\text { припин. викон. робіт) тис осіб }\end{array}$ & 14,5 & 2,2 & 1,6 & 0,7 & 3,4 & 1,4 & 2,7 & -2 & $-13,1$ & 385,7 & $-58,8$ & $-90,3$ \\
\hline $\begin{array}{l}\text { Кількість працівників, переве- } \\
\text { дених } 3 \text { економічних причин на } \\
\text { неповний робочий день } \\
\text { (тиждень), тис. осіб }\end{array}$ & 34,2 & 11,1 & 12,8 & 10,3 & 8,7 & 7,1 & $-1,6$ & $-1,6$ & $-27,1$ & $-15,5$ & $-18,4$ & $-79,2$ \\
\hline $\begin{array}{l}\text { у відсотках до } \\
\text { облікової кередньо- } \\
\text { працівникості } \\
\text { штатних }\end{array}$ & 17,1 & 6,2 & 7 & 6,1 & 5,1 & 4,1 & -1 & -1 & -13 & $-16,4$ & $-19,6$ & $-76,0$ \\
\hline
\end{tabular}

Примітка. Побудовано автором за даними [1-5]. 
Економічні науки: збірник наукових праџь Луцького національного технічного університету. - Серія "Регіональна економіка". - Випуск 15 (59). - Редкол.: відп. ред. д.е.н., професор Л.Л. Ковальська - Луцьк : ІВВ Луцького НТУ, 2018. -292 с.

Аналізуючи зміну цього показника у відсотках до середньооблікової кількості штатних працівників, можна також відмітити його зниження - 3 7,3\% у 2015 році до $0,8 \%$ у 2017 році, що свідчить про суттєве зменшення втрат робочого часу з цих причин. Важливе значення також має вивчення зміни кількості працівників, переведених 3 економічних причин на неповний робочий день (тиждень).

Цей показник також характеризувався тенденцією до зниження - 3 34,2 тис. осіб у 2010 році до 7,1 тис осіб у 2017 році, що також свідчить про позитивні зміни. Зміна цього показника у відсотках до середньооблікової кількості штатних працівників також підтверджує попередні тенденції, адже відбулося його поступове зниження - 3 17,1\% у 2010 році до 4,1\% у 2017 році.

Поряд 3 аналізом основних показників важливе значення має вивчення загальних тенденцій зміни показників використання робочого часу працівників у регіоні. Для цього вивчено загальну динаміку використання робочого часу (відпрацьовано у \% до табельного фонду робочого часу) у Волинській області за 2010-2017 рр. (рис. 1).

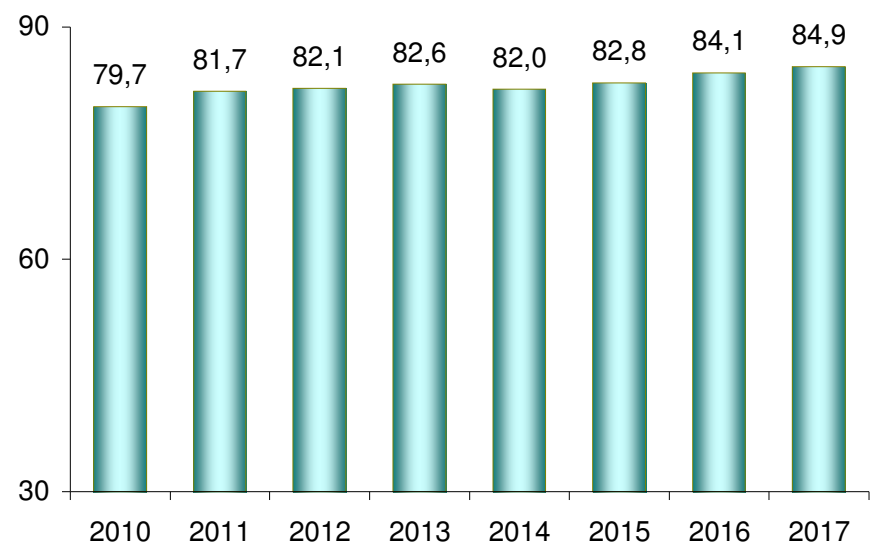

Рис. 1. Динаміка використання робочого часу (відпрацьовано у $\%$ до табельного фонду робочого часу) у Волинській області за 2010-2017 рр. (побудовано за [1-5]) 
Економічні науки: збірник наукових праџь Луцького національного технічного університету. - Серія "Регіональна економіка". - Випуск 15 (59). - Редкол.: відп. ред. д.е.н., професор Л.Л. Ковальська - Луцьк : ІВВ Луцького НТУ, 2018. -292 с.

Як бачимо, частка відпрацьованого часу у загальному табельному фонді робочого часу має стійку тенденцію до зростання - $379,7 \%$ у 2010 році до 84,9\% у 2010 році. При цьому, лише у складному з економічних причин 2010 році відбулося зниження цього показника порівняно з попереднім роком. Адже цей період характеризувався економічною нестабільністю діяльністі підприємств у зв'язку з посиленням загроз національній безпеці нашої країни, викликаних проведенням АТО на сході нашої країни.

Але після 2015 року спостерігалося різке підвищення цього показника - 3 82,8\% у 2015 році до 84,9\% у 2017 році. Все це свідчить про наявність позитивних тенденцій щодо раціоналізації використання робочого часу у регіоні. Це $\epsilon$ свідченням продуманої політики керівників підприємств, які забезпечують стабільну роботу підприємств у складний період економічного відновлення нашої країни та регіону зокрема. Разом 3 тим, понад $15 \%$ робочого часу залишається втраченим та потребує подальшої реалізації заходів щодо усунення різного роду об'єктивних чи суб'єктивних втрат робочого часу на регіональному рівні.

На наступному етапі аналізу проведено порівняння динаміки відпрацьованого робочого часу працівників у Волинській області за 2012-2017 рр. (рис. 2).

Як бачимо 3 рисунка, спостерігається тенденція до зростання відпрацьованого часу в середньому одним працівником за період 2012-2014 pp. - 31673 год до 1695 год. Надалі у кризовому 2015 році відбулося зниження цього показника до рівня 1692 год, а у 2016 році - його різке зростання до 1739 год, що відбулося за рахунок певного відновлення економічної стабільності у регіоні. Але у 2017 році цей показник знову різко зменшився до 1679 год. Відповідно, паралельний аналіз зміни показника частки відпрацьованого часу у \% до табельного фонду робочого часу також свідчить про подібні тенденції використання робочого часу. 
Економічні науки: збірник наукових праць Луиякого національного технічного університету. - Серія "Регіональна економіка". - Випуск 15 (59). - Редкол.: відп. ред. д.е.н., професор Л.Л. Ковальська - Луцьк : ІВВ Луцького НТУ, 2018. -292 с.

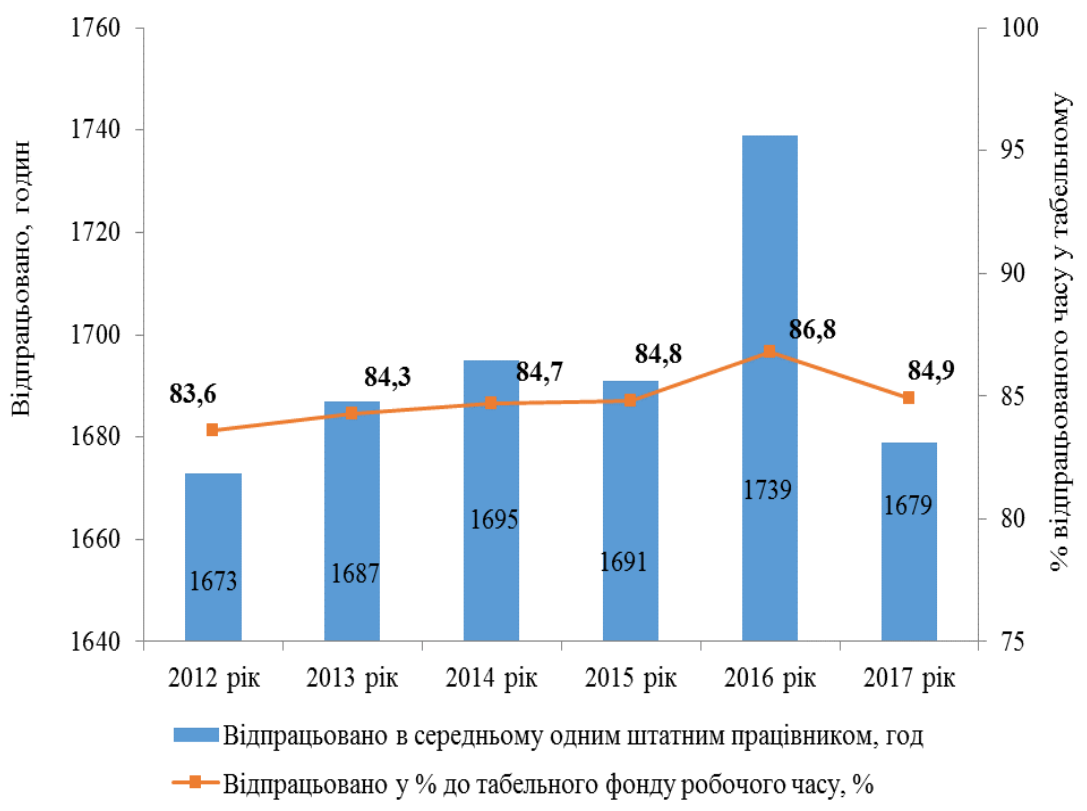

Рис. 2. Порівняння динаміки відпрацьованого робочого часу працівників у Волинській області за 2012-2017 pp. (побудовано за даними [1-5])

Поряд 3 вивченням загальних тенденцій проведено ранжування видів економічної діяльності за зміною відпрацьованого часу в розрахунку на одного штатного працівника у Волинській області у 2017 році та порівняння 3 даними 2015 року (рис. 3).

Підтверджуються раніше зроблені висновки, що сфери освіти, відпочинку і розваг, надання інших видів послуг, охорони здоров'я, професійної та наукової діяльності, які відносяться до галузей невиробничої сфери демонструють рівень використання робочого часу в межах 78,9-84,8\%. А галузі виробничої сфери та сфери обігу (торгівлі) забезпечують значно вищий рівень використання робочого часу, який змінюється у межах 89,3-90,4\%. 
Економічні науки: збірник наукових праць Луиякого національного технічного університету. - Серія "Регіональна економіка". - Випуск 15 (59). - Редкол.: відп. ред. д.е.н., професор Л.Л. Ковальська - Луцьк : ІВВ Луцького НТУ, 2018. -292 с.

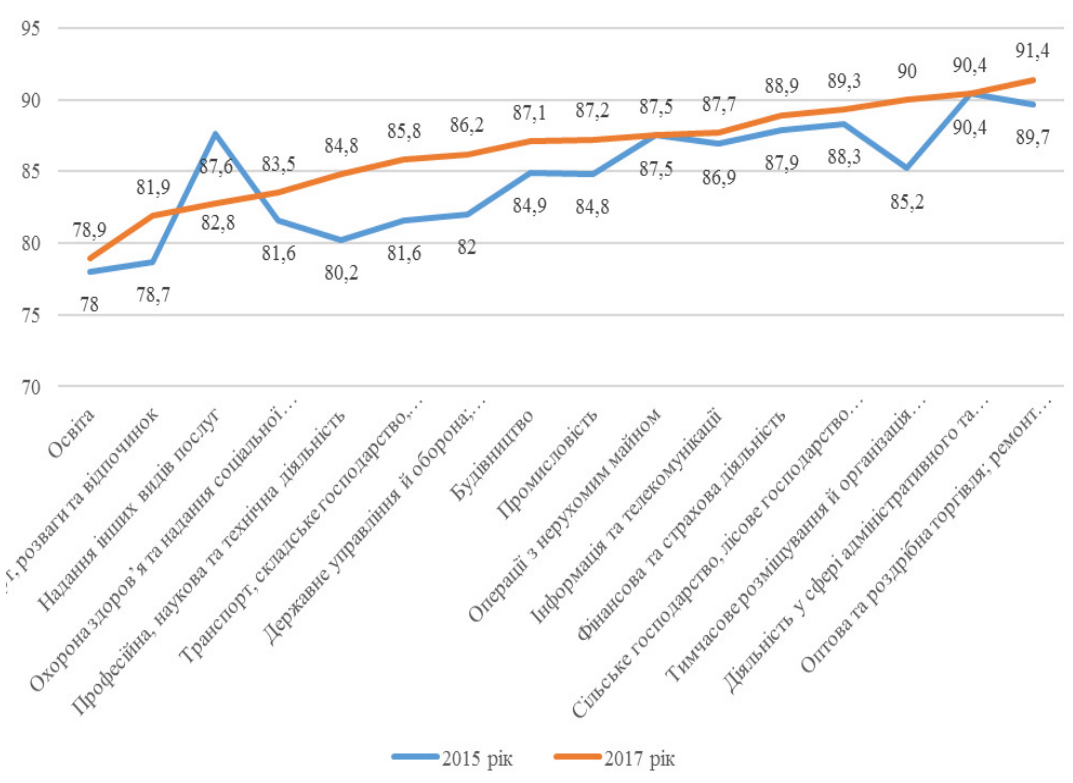

Рис. 3. Ранжування видів економічної діяльності за зміною відпрацьованого часу в розрахунку на одного штатного працівника у Волинській області у 2017 році та порівняння 3 даними 2015 року (побудовано за даними [1-5])

Поряд 3 цим можна також відміти певне зростання за більшістю видів економічної діяльності рівня використання робочого часу у регіоні у 2017 році порівняно з 2015 роком, хоча у сфері надання інших послуг він знизився з 87,6\% у 2015 році до 82,8\% у 2017 році, що свідчить про погіршення використання робочого часу в цій сфері.

3 метою вивчення закономірностей та прогнозування тенденцій використання робочого часу у регіону побудовано регресійну модель прогнозування показника відпрацьованого часу у \% до табельного фонду робочого часу у Волинській області за 2010-2017 рр. (рис. 4). 
Економічні науки: збірник наукових праџь Луцького національного технічного університету. - Серія "Регіональна економіка". - Випуск 15 (59). - Редкол.: відп. ред. д.е.н., професор Л.Л. Ковальська - Луцьк : ІВВ Луиьккого НТУ, 2018. -292 с.

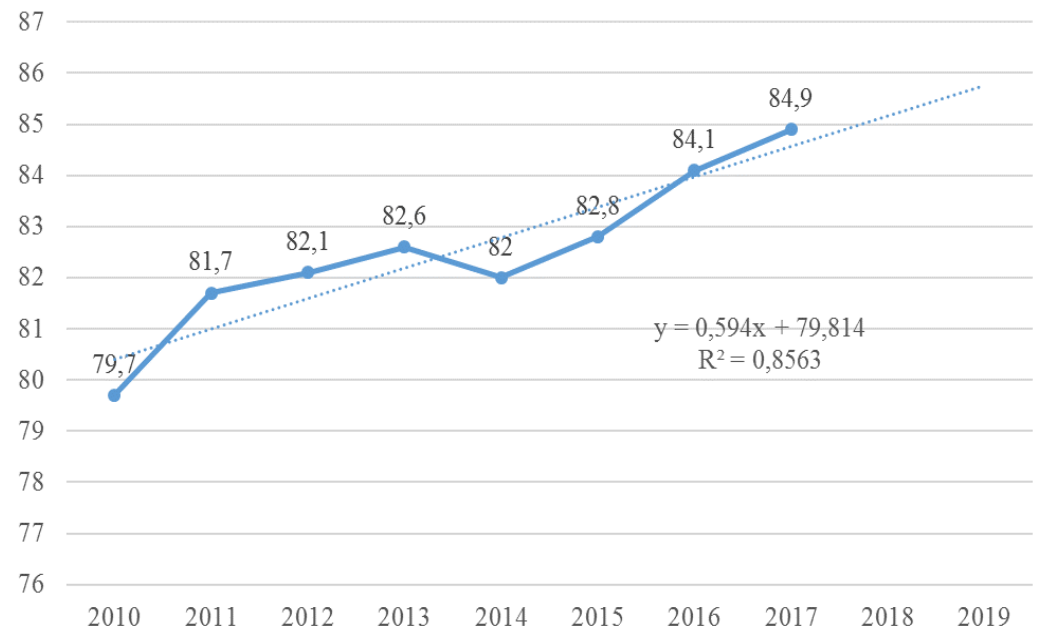

Рис. 4. Регресійна модель прогнозування показника відпрацьованого часу у \% до табельного фонду робочого часу у Волинській області за 2010-2017 рр. (побудовано за [1-5])

За результатами регресійного аналізу виявлено, що зміна показника відпрацьованого часу у \% до табельного фонду робочого часу у Волинській області за даними за період 2010-2017 pp. найкращим чином описується за допомогою лінійної моделі. Результати прогнозування свідчать, що тенденція до зростання рівня відпрацьованого часу у \% до табельного фонду робочого часу у Волинській області буде продовжуватися та до 2019 року цей показник може досягнути рівня $86 \%$. Тобто передбачаються переважно позитивні зміни до зростання рівня використання робочого часу у регіоні.

Висновки. Отже, характеризуючи тенденції зміни відпрацьованого часу в розрахунку на одного штатного працівника у Волинській області можна зробити висновок, що найнижчий рівень переважно забезпечують галузі невиробничої сфери, які відносяться до бюджетної сфери, де дотримуються соціальні гарантії працівникам, які перебувають у тимчасовій непрацездатності або у відпустках, тоді як у галузях виробничої 
Економічні науки: збірник наукових праџь Луцького національного технічного університету. - Серія "Регіональна економіка". - Випуск 15 (59). - Редкол.: відп. ред. д.е.н., професор Л.Л. Ковальська - Луцьк : ІВВ Луиького НТУ, 2018. -292 с.

сфери цей показник є як правило вищим, адже роботодавці стимулюють працівників раціонально використовувати робочий час, адже від цього залежить рівень оплати праці та сума витрат роботодавця на утримання персоналу.

Загалом можна зробити висновок, що у сфері використання робочого часу у регіоні відбуваються переважно позитивні зміни. Адже забезпечується зростання показника відпрацьованого часу у розрахунку на одного працівника, а невідпрацювання 3 причин відпусток без збереження заробітної плати або переведення на неповний робочий день (тиждень). Відповідно, спостерігається стійка тенденція до зменшення й кількості працівників, які знаходились у відпустках без збереження заробітної плати (на період припинення виконання робіт), а також переведених з економічних причин на неповний робочий день. Це в цілому свідчить про забезпечення більш повного використання робочого часу у регіоні.

1. Праця Волині-2015: статистичний збірник / За ред. В.О. Грабаровської. Луцьк: Головне управління статистики у Волинській області, 2016. - 116 с.

2. Праця Волині-2016: статистичний збірник / За ред. В.О. Грабаровської. Луцьк: Головне управління статистики у Волинській області, 2017. - 103 с.

3. Праця Волині-2017: статистичний збірник / За ред. В.О. Грабаровської. Луцьк: Головне управління статистики у Волинській області, 2018. - 117 с.

4. Волинь-2016: статистичний щорічник / За ред. В.Ю. Науменка. - Луцьк: Головне управління статистики у Волинській області, 2017. - 457 с.

5. Головне управління статистики у Волинській області: офіційний веб-сайт [Електронний pecypc]. - Режим доступу: http://www.lutsk.ukrstat.gov.ua. 